\title{
Diversity and endemism of tree ferns (Cyatheaceae: Polypodiopsida) in the Central Andes along latitudinal and elevation gradients
}

\author{
Adrian Tejedor \\ School for Field Studies
}

\section{Correspondencia}

A. Tejedor

e-mail: adriantejedor@gmail.com

Recibido: 21 junio 2017

Aceptado: 21 julio 2017

Publicado on-line: diciembre 2017

\begin{abstract}
Tree ferns are a conspicuous and yet poorly known component of Neotropical montane forests. Conservation efforts for these plants are hindered by a lack of information of patterns of species richness and endemism, which has been in turn prevented by an unstable taxonomy and limited collections. Based on distribution data from the most recent floristic accounts of tree ferns from Peru, Bolivia, and Argentina, this study presents an analysis of species richness and endemism of this group in the Central Andes. Results show that tree fern diversity falls steeply with distance from the equator, and the effect is stronger in the lowlands than at tree line to $-20^{\circ}$. In elevation, tree fern species richness shows a bimodal distribution with peaks at 1000 and $2100 \mathrm{~m}$, where as many as 24 species can coexist in 200 m elevation intervals. Endemic species are concentrated in the northern Central Andes. Endemics in more southern latitudes tend to be restricted to higher elevations. Correspondingly, the tree fern flora of the southern Central Andes is mostly composed of widely ranging species, potentially tolerant of higher seasonality and longer term climatic fluctuations. These results provide a tool for predicting how many tree fern species should be found in any given area of the Central Andes, even those botanically unexplored, and indicates areas where species richness and endemism is concentrated, and may serve to guide efforts aimed to conserve tropical montane forests.
\end{abstract}

Key words: Tree ferns, diversity, endemism, Central Andes, Peru

\section{Resumen}

Diversidad y endemismo de los helechos arborescentes (Cyatheaceae: Polypodiopsida) en los Andes Centrales a lo largo de gradientes de latitud y elevación.

Los helechos arborescentes son un componente conspicuo pero poco conocido de los bosques montanos Neotropicales. Su taxonomía inestable y limitadas colecciones han dificultado el análisis de sus patrones de riqueza y endemismo y por lo tanto de su conservación. Este estudio presenta un análisis de riqueza y endemismo de helechos arborescentes en los Andes Centrales sobre la base de tratados florísticos de este grupo para Perú, Bolivia y Argentina. Los resultados muestran que la diversidad declina rápidamente con la distancia al ecuador, y el efecto es más marcado en tierras bajas que a lo largo del límite superior del bosque hasta los $-20^{\circ}$. En elevación, la riqueza muestra una distribución bimodal con picos a 1000 y $2200 \mathrm{~m}$, en los cuales pueden coexistir hasta 25 especies en intervalos de elevación de 200 m. Los endémicos están concentrados en los Andes Centrales del norte. En latitudes más australes, los endémicos tienden a estar distribuidos a mayores elevaciones. Por consiguiente, los Andes Centrales del sur están dominados por especies de amplia distribución, potencialmente tolerantes a mayor estacionalidad y mayores fluctuaciones climáticas de largo plazo. Estos resultados sirven como herramienta para predecir la riqueza y endemismo de los helechos arborescentes en cualquier punto a lo largo de los Andes Centrales y para guiar esfuerzos de conservación en los bosques montanos Neotropicales.

Palabras clave: Helechos arborescentes, diversidad, endemismo, Andes Centrales, Perú 


\section{Introduction}

Cyatheaceae are one of the most diverse fern families, with more than 600 species worldwide (Smith et al., 2008) and constitute a dominant vegetation element in tropical montane forests (Large and Braggings, 2004). A previous analysis of geographic patterns of tree fern community richness and endemism in the Americas (Rodríguez-Barahona et al., 2011) showed that in the New World, Cyatheaceae are most diverse along wet slopes of the Andes and southern Central American mountains within $10^{\circ}$ of latitude north and south of the equator, with outlying local centers of richness in the Brazilian Atlantic Forest, and the southern Guiana Highlands. The results of Rodríguez-Barahona et al. (2011), however, are based on web databases that often suffer from spotty geographic sampling (Feeley and Silman 2011) and from specimen misidentification (Goodwin et al., 2015). Moreover, while these results are suitable to guide conservation efforts at continental scales, their usefulness is limited at country or province scales, where most of the prioritization of conservation areas is actually made (Possingham et al., 2006). The present study offers a more fine-grained analysis of patterns of diversity and endemism of tree ferns in the Central Andes, with an emphasis on Peru, based on recent floristic and taxonomic work (Lehnert, 2009; 2011; Lehnert and Tejedor, 2016; Márquez, 2010; Martínez, 2014) and on the assumption of non-disjunct distributions. These results provide a tool for predicting tree fern species richness in the Central Andes and for identification of areas important for the conservation of this group and tropical montane forests.

\section{Methods}

Given that avoiding potentially misidentified herbarium accessions was a major concern of this study, analyses were based on a database of presence/absence at second order political units (regions in Peru, departments in Bolivia, and provinces in Argentina) and minimum and maximum elevation records obtained from floristic treatments and species descriptions (Lehnert, 2009; 2011; Lehnert and Tejedor, 2016; Márquez, 2010; Martínez, 2014). This approach required assuming non-disjunct distributions. Political units where a particular species had not been recorded and which lay in between political units with known occurrences of that species were assumed to have presence of that species. This database was used to construct graphs of elevation range of species in every political unit. Based on the graphs, a matrix of elevation by latitude was built recording the presence or absence of species at $200 \mathrm{~m}$ elevation intervals. Latitudes were obtained from the centroid of every political unit. This matrix was used to calculate the total number of species in every political unit, to generate graphs of species richness by elevation in every political unit, and to produce an interpolation graph of species richness across both elevation and latitude. Graphs were made using the software packages Microsoft Excel, PAST (Hammer et al., 2001), and Origin (OriginLab, Northampton, MA, USA).

Maps for every species occurring in Peru were made with DIVA-GIS (http://diva-gis.org/) assuming, again, non-disjunct distributions between the northernmost and southernmost localities and the highest and lowest elevations known for each species. Richness maps, based on overlapping individual species maps, were generated in ArcGIS (Esri). Widespread Andean species were defined as those species that range from Venezuela, Colombia, or Ecuador south into Bolivia. Northern Andean species were defined as those that range from Venezuela, Colombia, or Ecuador south into Peru but not Bolivia. This definition was used to assess patterns only within Peru. Central Andean species excluding Peruvian endemics (treated as Central Andean species in the strict sense) were defined as those that range from the south of the Huancabamba depression in northern Peru into Bolivia. In the analysis of endemism vs. elevation, only species distributed in Peru and Bolivia, were included because only those have published northernmost and southernmost localities. Distribution of collection localities for Cyatheaceae as a family but not for individual species used to compare density of collection localities vs. species richness curve was obtained from Tropicos database. All statistical significance analyses were performed using PAST (Hammer et al., 2001). Correlation significance was assessed with Pearson correlation tests, and mean elevations between central Andean species vs. widespread species were compared with a T-test.

\section{Results}

Across latitude and elevation along the Central Andes, tree fern species richness is highest in northern Peru (Amazonas-Cajamarca) on the Andean foothills (around $1000 \mathrm{~m}$ ) and middle elevations (around $2100 \mathrm{~m}$ ), where as many as 2224 species can potentially coexist. Tree fern species richness is lowest, on the other hand, in southern Bolivia (Chuquisaca) and northern Argentina (Salta-Jujui), where only one species, the Bolivian- 
Tucuman forest endemic Alsophila odonelliana (Alston) Lehnert, is found between 1000 and 1900 $m$ (fig. 1A). Overall, tree fern species richness decreases markedly with increasing distance from the equator (fig. 1B; $R^{2}=0.94 ; P<0.01$ ). In Peru, potential richness across elevation has a humped shape, with a tendency to being bimodal (figs. 1A and $1 \mathrm{C}$ ), but richness maxima shift upslope to 2100 $\mathrm{m}$ toward the south (e.g. in Cusco). At the upper limits of tree fern distribution (elevations above

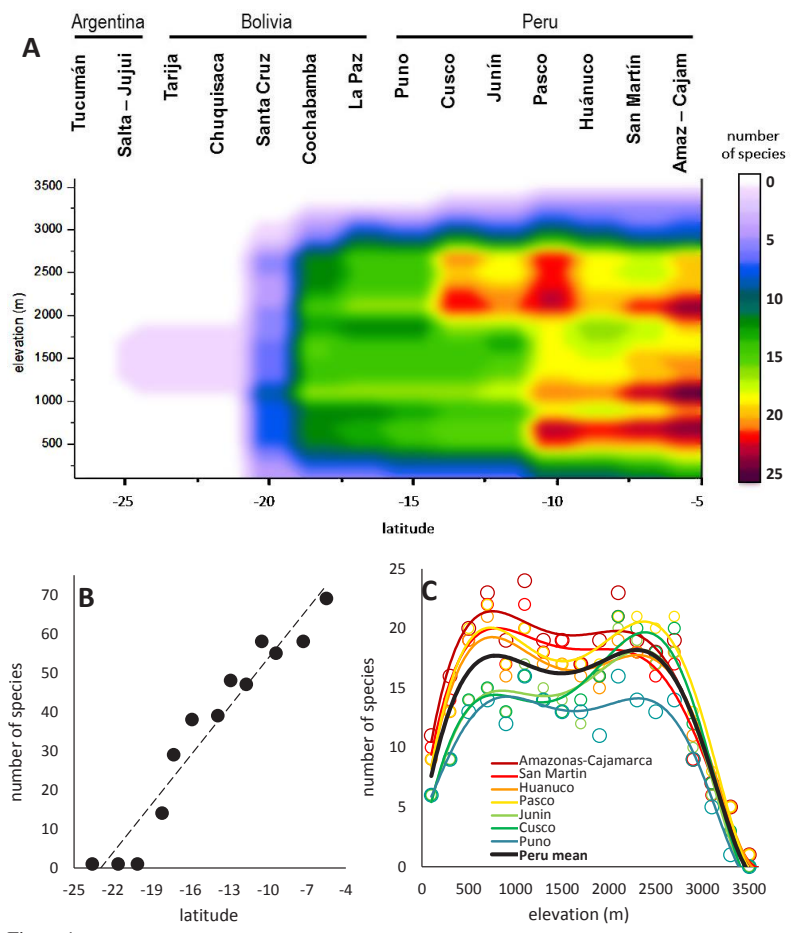

Figure 1. A. Potential species richness of tree ferns across latitude and elevation in the Central Andes. B. Relationship of tree fern species richness with latitude only. Tree fern species richness decreases markedly with increasing distance from the Equator. C. Potential number of tree fern species in seven regions of Peru (colored lines) and average potential number of species across elevation for the entire country (black line). Open circles are expected species richness every 200 $m$ elevation intervals based on species range overlap and lines are $6^{\text {th }}$ order polynomial functions. Figura 1. A. Distribución a lo largo de los gradientes de latitud y elevación de la riqueza potencial de especies de helechos arborescentes en los Andes Centrales. B. Relación entre la riqueza de especies y la latitud solamente. La riqueza de especies disminuye rápidamente con un incremento de la distancia hacia el ecuador. C. Riqueza potencial de helechos arborescentes en siete regiones de Perú (líneas coloreadas) y promedio de riqueza de especies para todo Perú (línea negra). Los círculos representan la riqueza esperada cada $200 \mathrm{~m}$ de elevación con base en la yuxtaposición de distribuciones. Las líneas son polinomios de 6 to orden.
$3000 \mathrm{~m}$ ), latitude has little effect on species richness from northern Peru to central Bolivia. Latitude has a stronger effect in the lowlands, where tree fern communities are nearly twice as rich in northern Peru (10-15 species) compared to those in southern Peru (4-9 species). A map of species richness in Peru also shows a clear decline in species numbers from north to south but the trend is puntuated by

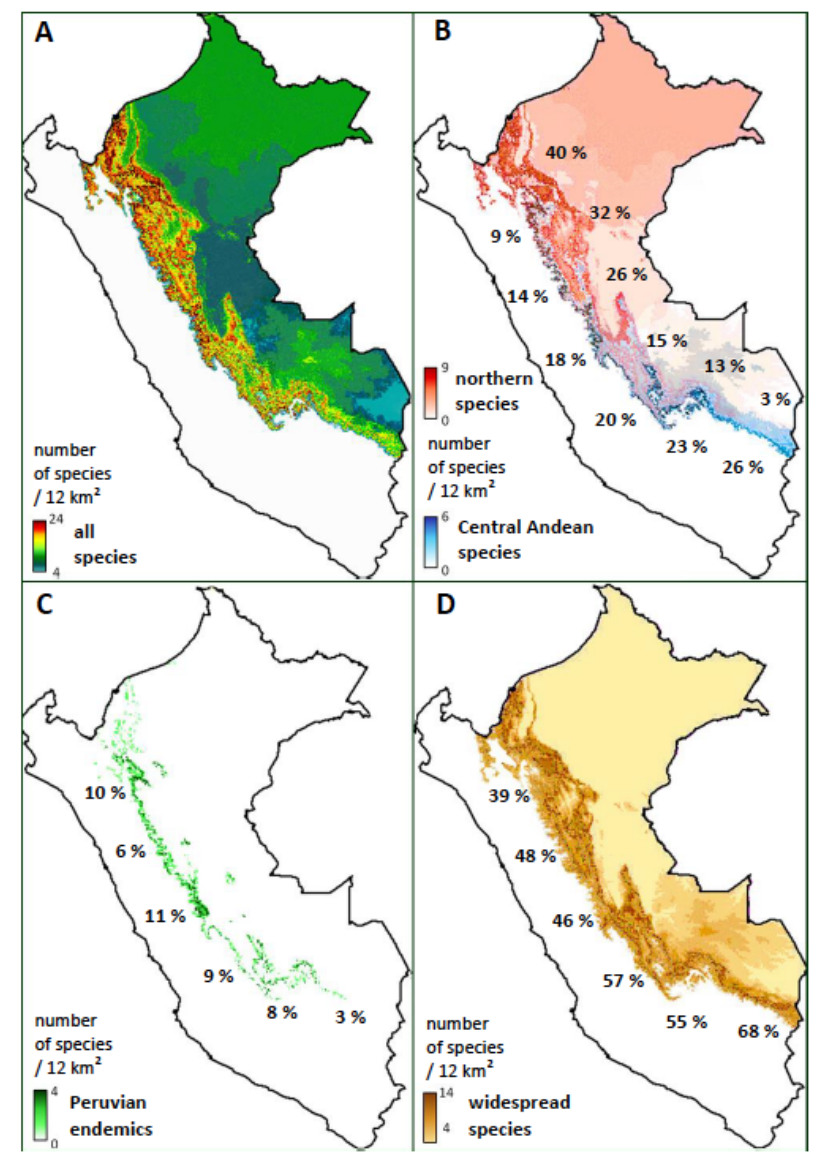

Figure 2. Geographic distribution of species richness of tree ferns in Peru and contribution of four floristic components (see definition under Methods) to Central Andean tree fern diversity. A. all species. B. Northern species (red), Central Andean species (blue). C. Peruvian endemics. D. Widespread species. The percentages indicate the proportion contributed by each component to regional floras at six latitudes from northern to southern Peru. Figura 2. Distribución geográfica de la riqueza potencial de especies de helechos arborescentes en Perú y contribución a la diversidad de cuatro componentes florísticos definidos en la sección de métodos. A. Todas las especies. B. Especies con distribución norteña (en rojo) y especies endémicas de los Andes Centrales (en azul). C. Endemicos peruanos. D. Especies de distribución amplia. Los porcientos indican la contribución relativa de cada componente a la flora regional en seis latitudes desde el norte hasta el sur del Perú. 
the highly dissected topography of the Andes and by the two elevation bands of maximum richness. In spite of the resulting patchy mosaic of species richness along the Andean slope, the overall steep North-South gradient of species richness in the Central Andes remains evident (fig 2A).

Endemism among Andean tree ferns is also influenced by both latitude and elevation. Central Andean endemics in a broad sense $(30 \%$ of the flora), split here between those found only in Peru (Peruvian Endemics, $15 \%$ ) and those shared between Peru and Bolivia (here called "Central Andean endemics" in a strict sense, $15 \%$ ) are mostly confined to mid-high elevations (fig $2 \mathrm{~B}, \mathrm{C}$ ). Northern species (33\% of the Central Andean flora, fig. $2 \mathrm{~B}$, see methods for definition) dominate the lowland flora in northern Peru, whereas widespread Andean and Amazonian species (32\%, dominate mid and lower elevations in southern Peru (fig. 2D). The dominance of widespread species increases with distance from the Equator (fig 2D). In latitude, Peruvian endemics are mostly concentrated along a band stretching from northern (Amazonas/N San Martin, $-5^{\circ}$ ) to central Peru (Pasco, $-10^{\circ}$, fig. $2 \mathrm{C}$ ). Overall, species with range mid points at more southern latitudes tend to be distributed at higher elevations in the Central Andes (fig 3).

\section{Discussion}

Tree fern species richness in the Central Andes shows a steep decline with increasing distance from the Equator, losing linearly an average $6 \%$ of species per degree of arc, with northern Peru having $45 \%$ more species than northern Bolivia. This pattern stands in sharp contrast to that found for all ferns in general at both regional (Kreft et al., 2010) and plot scales (Salazar et al., 2013), which shows virtually no change in species richness between Ecuador and northern Bolivia. This decline in species numbers also exceeds that of all other vascular plants (Mutke and Barhlott, 2005), which within the South American tropics lose on average $1 \%$ of species per degree of arc. The decline in species richness for tree ferns, on the other hand, is most similar to that of palms (Bjorholm et al., 2006), which lose on average 5 $\%$ of species per degree of arc from the equator to $-15^{\circ}$. Thus, tree ferns species richness is favored by the proximity to the equator much more than that of most other plants. Given that the northernmost latitude included in this study is only $-4^{\circ}$, extending the analysis further to northern South America and into Central America should confirm whether there is indeed an equatorial peak in Andean tree fern species richness (as suggested here and by
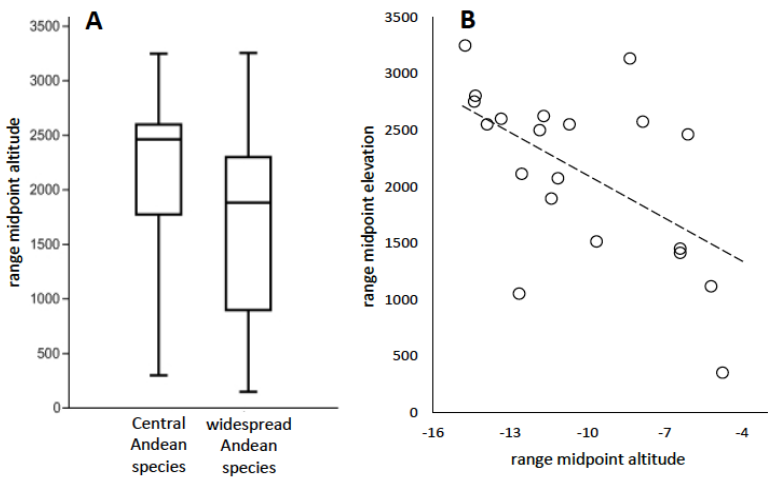

Figure 3. A. Central Andean species, including Peruvian endemics, are on average distributed at higher elevations than widespread Andean species. B. Among Central Andean species there is a weak but significant negative correlation between latitude and elevation of range midpoint $\left(R^{2}=0.34, P<0.01\right)$. Southern species tend to be distributed at higher elevations than northern species. Figura 3. A. Las especies de helechos arborescentes endémicas de los Andes Centrales, incluyendo a los endémicos peruanos, están distribuidos en promedio a elevaciones mayores que las especies de amplia distribución en los Andes. B. Entre las especies de los Andes Centrales hay una correlación negativa leve pero significativa entre la altitud y la elevación del punto central de distribución de cada especie $\left(R^{2}=0.34, P<0.01\right)$. Las especies distribuidas con centros de distribución más al sur tienden a ocupar elevaciones más altas que las especies con centros de distribución más al norte.

Ramírez-Barahona et al., 2016) or whether species richness plateaus in northern Colombia and Costa Rica as shown by Ramírez-Barahona et al. (2011).

The tight latitudinal trend of regional species richness in tree ferns documented here does not seem to be associated with absolute precipitation, which is spotty along the eastern flanks of the Andes and has maxima at $-13^{\circ}$ and $-17^{\circ}$ (Killeen et al., 2007), rather than in northern Peru. It may be, instead, associated with precipitation and temperature seasonality, which increases consistently with latitude from the equator to the Tropic of Capricorn along the eastern flank of the Andes and western Amazon (Garreaud, 2009; Wung and Fu, 2002). The steeper decline in species numbers with latitude in the lowlands points more specifically at precipitation seasonality as a major correlate of species richness. Along Andean slopes, precipitation seasonality is buffered by year-round orographic rain (Killeen et al., 2006) and could allow drought susceptible species to persist further away from the equator than expected based on the seasonal fluctuation of the ITCZ (Garreaud, 2009).

In elevation, the apparent bimodal distribution 
of richness found here among tree ferns is striking, deviating from the unimodal hump found for all ferns in the Neotropics (Salazar et al., 2013) and other tropical regions (Kessler et al., 2011). The species richness maxima found here coincide with two elevations where many species ranges end and overlap: around $1000 \mathrm{~m}$, where lowland and premontane species (e.g. Alsophila cuspidata (Kunze) D.S. Conant, Cyathea lasiosora (Mett. ex Kuhn) Domin, Cyathea leucolepismata Alston, and Cyathea subincisa (Kunze) Domin) intergrade with lower montane species (e.g. Cyathea bipinnatifida (Baker) Domin, Cyathea uleana (Samp.) Lehnert, and Cyathea ulei (Christ) Domin); and $2000 \mathrm{~m}$, where lower montane species intergrade with montane species (e.g. Cyathea carolihenricii Lehnert, Cyathea catacampta Alston, Cyathea herzogii Rosenst., and Cyathea ruiziana Klotzsch). These areas of overlap also appear to coincide with climatic or otherwise vegetation boundaries such as the band of maximum annual precipitation along Andean foothills (Killeen et al., 2007) and cloud base around 1800 m (Gentry, 1988; Rapp, 2010). Corroborating the bimodal species richness with plot data and assessing whether elevation floristic transitions among tree ferns are related with climatic boundaries could be fruitful future research avenues.

The concentration of endemics at mid to high elevations found among Central Andean tree ferns mirrors previous findings for Andean plants (Balslev, 1988; Kessler, 2000; Kessler, 2001). The decrease in the richness of endemics toward the south is accompanied by a proportional increase in the richness of wide-ranging species, which span much of the length of the tropical Andes. This floristic substitution also points to seasonality as a major factor affecting tree fern species distribution and richness. As seasonality increases, as it does along the Central Andes and adjacent lowlands with distance from the equator (Garreaud, 2009; Wung and $\mathrm{Fu}, 2002$ ), only species with broader niches (Mori and Chuine, 2006) and greater tolerance of desiccation (Baltzer et al., 2008) may be able to cope with longer dry spells. Testing the relationship between physiology and size and latitude of tree fern species ranges remains a tantalizing question for future studies.

The results presented here provide a tool for predicting how many tree fern species are to be found in any given area of the Central Andes, even those botanically unexplored. Because of the approach followed with this study (i.e. the assumption of nondisjunct ranges), species numbers at any given 200 $\mathrm{m}$ interval along the Andean slope have the risk of being overestimated and thus should be interpreted

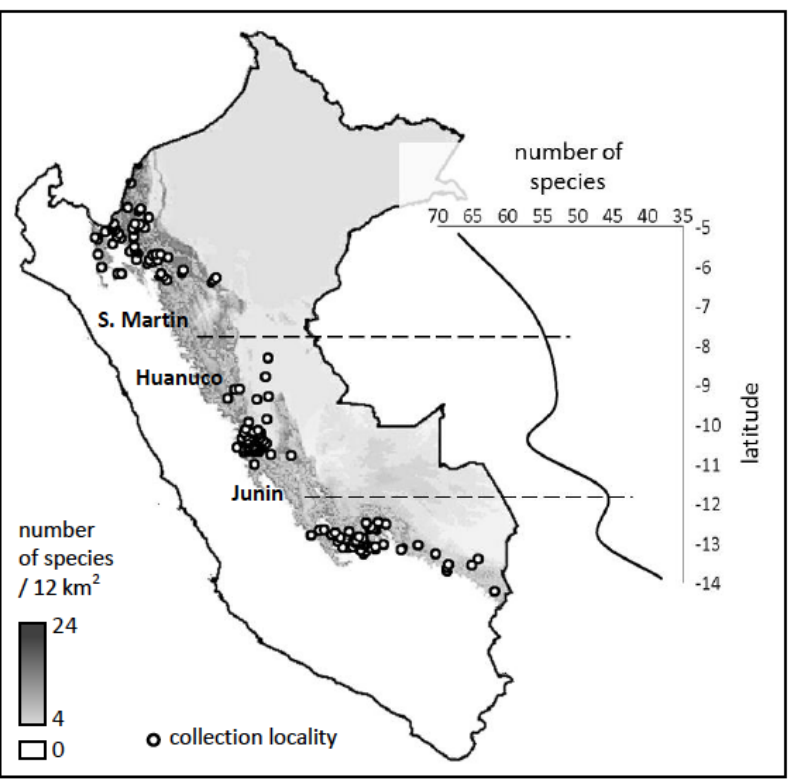

Figure 4. Tree fern species richness in Peru in relation to collection localities. The base map shows overall tree fern species richness. Figura 4. Riqueza de especies de helechos arborescentes en Peru en relación a localidades de colecta. El mapa de base muestra riqueza de especies.

as the maximum richness expected for any of those intervals. Still, even under the non-disjunct distribution assumption, collection gaps continue to affect the Central Andean species richness curve at least in Peru (fig 4). Apparent species-poor valleys in the species richness curve, which correspond to central San Martín-Huanuco and Junín, are likely artifacts of the paucity of collection efforts. Future sampling in these areas should be expected to bring their number of species up, smoothing out the species richness curve and likely facilitating analyses of environmental correlates of diversity. Nonetheless, the patterns presented here are a good starting point to understand the distribution of richness and endemism of Central Andean tree ferns and may serve to guide national and regionalscale efforts to conserve tropical montane forests.

\section{Conclusions}

From the equator south along the Central Andes, tree ferns show one of the steepest latitudinal gradients of species richness among vascular plants. In contrast to ferns in general, Central Andean tree ferns do not have a single maximum of species richness at middle elevations but rather two peaks, at 1000 and $2100 \mathrm{~m}$. In the Central Andes, tree fern endemism is concentrated 
at middle to high elevations in the northern part of the region, with widespread Andean species dominating the flora in the south. Precipitation seasonality may be the most important factor affecting species richness, endemism, and floristic composition of Central Andean tree ferns.

\section{Acknowledgements}

I am grateful to Sylvia Gutierrez for help with data input and to Michael Kessler and Johanset Orihuela who offered constructive criticism to earlier versions of the manuscript.

\section{References}

Balslev, H. (1988). Distribution patterns of Ecuadorean plant species. Taxon, 37, 567-577.

Baltzer, J. L., Davies, S. J., Bunyavejchewin, S., \& Noor, N. S. M. (2008). The role of desiccation tolerance in determining tree species distributions along the Malay-Thai Peninsula. Functional Ecology, 22, 221231.

Bjorholm, S., Svenning, J.C., Baker, W.J., Skov, F., \& Balslev, H. (2006). Historical legacies in the geographical diversity patterns of New World palm (Arecaceae) subfamilies. Botanical Journal of the Linnean Society, 151, 113-125.

Feeley, K. J., Silman, M. R. (2011). The data void in modeling current and future distributions of tropical species. Global Change Biology, 17, 626-630.

Garreaud, R. D. (2009). The Andes climate and weather. Advances in Geosciences, 22, 3-11. http://www.advgeosci.net/22/3/2009/adgeo-22-3-2009.pdf

Gentry, A.H. (1988). Changes in plant community diversity and floristic composition on environmental and geographical gradients. Annals of the Missouri Botanical Garden, 75, 1-34

Goodwin, Z. A., Harris, D. J., Filer, D., Wood, J. R. \& Scotland, R. W. (2015). Widespread mistaken identity in tropical plant collections. Current biology, 25, 10661067. doi: 10.1016/j.cub.2015.10.002.

Hammer, Ø., Harper, D.A.T., \& Ryan, P.D. (2001). PAST: Paleontological statistics software package for education and data analysis. Palaeontologia Electronica, 4(1), 1-9.

Kessler, M. (2000). Altitudinal zonation of Andean cryptogam communities. Journal of Biogeography, 27, 275-282.

Kessler, M., Parris, B.S. \& Kessler, E. (2001). A comparison of the tropical montane pteridophyte floras of Mount Kinabalu, Borneo, and Parque Nacional Carrasco, Bolivia. Journal of Biogeography, 28(5), 611-622.

Kessler, M., Kluge, J., Hemp, A., \& Ohlemuller, R. (2011). A global comparative analysis of elevational species richness patterns of ferns. Global Ecology and Biogeography, 20, 868-880.

Killeen, T.J., Douglas, M., Consiglio, T., Jørgense, P.M., \& Mejía, J. (2007). Dry spots and wet spots in the
Andean hotspot. Journal of Biogeography (Special issue), 1-17.

Kluge, J., Kessler, M. \& Dunn, R.R. (2006). What drives elevational patterns of diversity? A test of geometric constraints, climate and species pool effects for pteridophytes on an elevational gradient in Costa Rica. Global Ecology and Biogeography, 15, 358371. https://www.researchgate.net/profile/Michael_ Kessler/publication/229682551

Kreft, H., Jetz, W., Mutke, J., Barthlott, W. (2010). Contrasting environmental and regional effects on global pteridophyte and seed plant diversity. Ecography, 33, 408-419. http://www.uni-goettingen. de/de/document/download/3bfe88977d84edb99e5e9 $584 c 9$.

Large, M. F. \& J. E. Braggins. (2004). Tree Ferns. Portland/Cambridge: Timber Press.

Lehnert, M. (2006). The Cyatheaceae and Dicksoniaceae (Pteridophyta) of Bolivia. Brittonia, 58, 229-244.

Lehnert, M. (2011). The Cyatheaceae (Polypodiopsida) of Peru. Brittonia 63, 11-45.

Lehnert, M., \& Tejedor. A. (2016). Three new scaly tree fern species ( Cyathea -Cyatheaceae) from the Amotape-Huancabamba Zone and their biogeographic context. American Fern Journal, 106(3), 175-190.

Márquez, G. J. (2010). La familia Cyatheaceae (Pteridophyta) en la Argentina. Boletin de la Sociedad Argentina de Botánica, 45(1-2), 173-182.

Martínez, O. G. (2014). A new species of Alsophila (Cyatheaceae) from the Tucuman-Bolivian forest. Brittonia, 67(1), 48-55.

Morin, X., \& Chuine, I. (2006). Niche breadth, competitive strength and rangesize of tree species: a trade-off based framework to understand species dis-tribution. Ecology Letters, 9, 185-195.

Mutke J, Barthlott W. (2005). Patterns of vascular plant diversity at continental to global scales. Biologiske Skrifter, 55, 521-531.

Possingham, H. P., Wilson, K. A., Andelman, S.J., \& Vynne, C. H. (2006). Protected Areas: Goals, limitations and designs. In M. J. Groom, G. K. Meffe, \& C. R. Carroll (Eds.) Principles of Conservation Biology. 3rd ed. (pp 509-533). Sunderland, MA: Sinauer Associates, Inc.

Ramírez-Barahona, S., Luna-Vega, I., Tejero-Díez, D. (2011). Species richness, endemism, and conservation of American tree ferns (Cyatheales). Biodiversity and Conservation, 20(1), 59-72. DOI 10.1007/s10531010-9946-2.

Ramírez-Barahona S, Barrera-Redondo J, Eguiarte LE. (2016). Rates of ecological divergence and body size evolution are correlated with species diversification in scaly tree ferns. Proceedings of the Royal Society B, 283, 20161098. DOI 10.1098/rspb.2016.1098.

Rapp, J.M. (2010). Climate Control on Plant Performance Across an Andean Altitudinal Gradient. PhD Dissertation Wake Forest University.

Salazar, L., Homeier, J., Kessler, M., Abrahamczyk, S., Lehnert, M., Krömer, T., \& Kluge, J. (2013). Diversity patterns of ferns along elevational gradients in Andean tropical forests. Plant Ecology and Diversity. http:// dx.doi.org/10.1080/17550874.2013.843036 
Smith, A., Pryer, K. M., Schuettpelz, E., Korall, P., Schneider, H., \& Wolf, A. (2008). Fern classification. In T. A. Ranker \& C. H. Haufler (Eds.) The biology and evolution of ferns and lycophytes. (pp. 107-133). Cambridge, UK: Cambridge University Press.

Smith, A. R., Leon, B., Tuomisto, H., Van Der Werff, H., Moran, R. C., Lehnert, M. \& Kessler, M. (2005). New records of pteridophytes for the flora of Peru. Sida, 21, 2321-2342.
Sosa et al. (2016), Historical reconstruction of climatic and elevation preferences and the evolution of cloud forest-adapted tree ferns in Mesoamerica. PeerJ, 4:e2696; DOI 10.7717/peerj.2696

Wang, H, \& Fu, R. (2002). Cross-equatorial flow and seasonal cycle of precipitation over South America. Journal of Climate, 15, 1591-1608. http://journals.ametsoc.org/doi/pdf/10.1175/15200442\%282002\%29015\%3C1591. 
